\title{
Az OECD hatÁSA AZ OKTATÁS GLOBÁLIS ÉS MAGYARORSZÁGI FEJLŐDÉSÉRE
}

\author{
HALÁSZ GÁBOR \\ ELTE PPK
}

Beérkezett: 2021. szeptember 2., elfogadva: 2021. október 22.

\begin{abstract}
E tanulmány témája az OECD hatása az oktatás globális és magyarországi fejlődésére. A nemzetközi kapcsolatok és a kormányközi szervezetek elméletének keretei között értelmezi az OECD szerepét, reflektálva a kritikai irodalom ezzel kapcsolatos megállapításaira. Elemzi, hogy a szervezet milyen módon alkalmazza az indikátorokat a nemzeti oktatáspolitikák befolyásolása érdekében, továbbá azokat az intézményi mechanizmusokat, melyek a hatásait közvetítik. Külön kitér arra, hogy Magyarország milyen módon használja az OECD által létrehozott tudást, és ennek milyen korlátjai vannak. Megállapításait a szerző részben az OECD-ben szerzett két és fél évtizedes személyes tapasztalataira alapozza.
\end{abstract}

Kulcsszavakः OECD, nemzetközi szervezetek, globalizálódás, a nemzetközi hatásmechanizmusok, oktatás és nemzetközi hatások

This paper focuses on the impact of OECD on the global and Hungarian development of education. He interprets the role of the OECD in the context of the theory of international relations and intergovernmental organizations, with reflections on the findings of the critical literature in this regard. It analyses how the organization uses indicators to influence national education policies, as well as the institutional mechanisms that mediate its effects. It specifically discusses how Hungary uses the knowledge created by the OECD and what its limitations are. The author bases his findings in part on his two and a half decades of personal experience in the OECD.

Keywords: OECD, international organisations, globalisation, mechanisms of international impact, education and international influences

Levelező szerző: Halász Gábor, 2144 Kerepes, Juhász Gyula u. 75. E-mail: halasz.gabor@ppk.elte.hu 
$\mathrm{H}$ a az oktatás globális fejlődésének történeti térképét valaki az OECD nélkül próbálná megrajzolni, valószínűleg valami nagyon más tárulna elé, mint az, amit ma ismerünk. Noha a modern tömegoktatási rendszerek történetileg nemzeti keretek között alakultak ki, és ma is nemzeti keretek között működnek, a kívülről jövő hatások mindig komoly szerepet játszottak a fejlődésükben. A fejlett világ legtöbb országába az elmúlt évtizedekben e hatások jelentős hányada az OECD közvetítésével érkezett, sőt, egy részüket egyenesen e szervezet maga generálta. Annak ellenére, hogy szinte kizárólag szimbolikus eszközök vannak birtokában, az oktatás globális fejlődését alakító ágensek közül e szervezet rendelkezik az egyik legnagyobb befolyással.

Ennek illusztrálására talán érdemes hosszabban idézni a globalizálódás oktatási hatásainak egyik legismertebb kritikusát, és egyik legalaposabb elemzőjét, Stephen J. Ballt, a University College London professzorát. Egy vele készült interjúban így fogalmazott: „az OECD nagyon befolyásos jelentésadó (discursive) batással van a politikai gondolkodásra. Sok országban a politikai gondolkodás kereteit, határait és lebetőségeit, legalábbis bizonyos mértékben, korlátozzák azok a nyelvek, feltételezések és koncepciók, amelyeket a Világbank és az OECD megfogalmaz, támogat, kihirdet, ír és beszél, konferenciákon, és beszélgetésekben az oktatási minisztériumokban tett látogatások és konferenciák során. [...] Ha például olyan dolgokat vizsgálunk, mint a felsőoktatás minőségbiztositása, ez az OECD politikai gondolkodásának diadalát mutatja. Az, amit az OECD 1990-es és 2000-es években számos dokumentumban kidolgozott, ma a gondolkodás világkerete arról, hogyan tudhatjuk meg, hogy az egyetemek jól müködnek-e vagy sem." (Avelar 2016.)

E tanulmány azzal a kérdéssel foglalkozik, milyen hatással volt az elmúlt évtizedekben az oktatás fejlődésére az OECD globális szinten és Magyarországon. Mivel több mint negyed évszázadot töltöttem el az OECD Oktatáskutatási és Innovációs Központja (CERI) Igazgató Tanácsának tagjaként - két alkalommal e testület elnökének a szerepét is betöltve, és ennek az időnek jelentős hányadában a szűkebb koordináló csoport, a „Bureau” tagja is voltam -, úgy éreztem, az a leghasznosabb, ha személyesebb hangvételü esszét írok, erősen támaszkodva személyes tapasztalataimra. Érdemes megemlíteni azt is, hogy korábban e témáról két magyar nyelvü írásom is megjelent (Halász 2002a, 2014), az ezekben írottakat nem ismétlem meg itt, az érdeklődő olvasó ezeket is használhatja forrásként.

\section{Globalizálódás: az OECD-hatás kontextusa}

Az olyan nemzetközi szervezetek oktatási hatását, mint amilyen az OECD, a globalizálódás kontextusában lehet értelmeznünk. E folyamat drámai módon átalakította azt a teret, melyben az oktatás világát értelmezzük és az ebben megjelenő problémákat kezeljük. A téma általam egyik leginkább figyelemre méltónak tartott kutatója, Antoni Verger szerzőtársaival pár éve megjelentetett könyvében (Verger et. al. 2018) az oktatás globalizálódásának kilenc olyan jellemzőjét foglalta össze, melyeket egyszerre szükséges látnunk ahhoz, hogy e komplex jelenséget értelmezni tudjuk. Ezek egyike a nemzetközi szervezetek szerepének felerősödése.

Fontos hangsúlyozni - miképpen az említett szerzők is teszik -, hogy a nemzetközi szervezetek köre jóval tágabb, mint az OECD-hez hasonlóké. Ebbe bele kell értenünk a nemzetközi térben müködő olyan nem kormányzati szervezeteket is, mint a különféle szakmai, civil és tudományos szervezetek, a jótékonysági vagy karitatív funkcióval bírók 
és az oktatási javakkal kereskedő multinacionális cégek. Ezek népesítik be az oktatási folyamatok értelmezésének és alakításának, az oktatási szakpolitikák formálódásának bővülő globális terét. Az OECD-t is ebben a térben kell elhelyeznünk.

\section{$\mathrm{A} z$ OECD mint kormányközi szervezet}

A nemzetközi kapcsolatokkal foglalkozó irodalom az OECD-t kormányközi szervezetként írja le. Ez azt jelenti, hogy szuverén államok kormányai egyeztek meg létrehozásáról, ezek válhatnak tagjaivá, és ezek ellenőrzik a müködését. Az általuk delegált, nagyköveti státusban lévő személyek közössége, a Tanács hagyja jóvá a szervezet müködését meghatározó dokumentumokat, e testület dönti el, ki legyen a vezetője, és persze azt is, hogy mekkora költségvetéssel gazdálkodjon és mire fordítsa az erőforrásait. A Tanács időnként úgy ülésezik, hogy miniszterek képviselik az országokat: a jelentős stratégiai döntéseket szinte mindig így hozzák. Egy-egy szakterületen - ilyen az oktatás is - a nemzeti minisztériumok által delegált, általában magas rangú tisztviselőkből álló tematikus bizottságok döntenek az adott területet érintő programokról, a keletkező elemzések tematikus fókuszáról, a felmerülő tartalmi kérdésekről, sőt a nyilvánosságra hozatalról is. Bármelyik kormány bármikor kiléphet a szervezetből vagy akár egy-egy programból is, ha nem elégedett a müködésével. Ha valamit szeretne megváltoztatni, szövetségeseket kereshet, és ha sikerül többeket maga mellé állítania, elérheti, amit akar.

Joggal vethető fel a kérdés: vajon a befolyással maga a szervezet rendelkezik-e, vagy az őt létrehozó és müködtető országok közössége, amely egyszerűen eszközként használja ezt az intézményt, hogy tagjai viselkedését befolyásolja. Azok, akik az OECD-t bírálják - ilyenek nem kevesen vannak, messze nem az említett Stephen J. Ball az egyetlen -, vajon a szervezettel hadakoznak-e vagy saját kormányukkal? Azzal a kormánnyal, amely - nyilván azért, mert több haszna, mint kára van ebből - tagja maradt a „klubnak”. Így például az a csaknem száz oktatáskutató, akik 2014 májusában aláírták azt a The Guardian nevü brit újságban megjelent nyílt levelet, melyet az OECD oktatási igazgatójának, Andreas Schleichernek címeztek, ${ }^{1}$ és amelyben a PISA vizsgálat azonnali leállítását követelték, talán logikusabb módon cselekedett volna, ha saját kormányához fordul. E vizsgálat elindítása politikai értelemben nem az OECD, hanem a szervezet mögött álló kormányok döntése volt, és leállításáról is csak ezek hozhatnának politikai döntést.

Vajon egy ilyen, szuverén kormányok által létrehozott szervezet tekinthetö-e olyan ágensnek, amely saját jogán, saját érdekek alapján cselekszik a nemzetközi térben ugyanúgy, ahogyan a szuverén államok? Erről megoszlanak az álláspontok. Vannak olyan kutatók, akik szerint nem kétséges, hogy az államok vagy kormányok által létrehozott nemzetközi szervezetek, amilyen az OECD is, miután létrejöttek, önálló életre kelnek és saját jogon cselekvő ágenssé válnak, amely már nem feltétlenül követi megbízói érdekeit. Egy sokat idézett tanulmány szerzői meggyőző módon érvelnek amellett, hogy ez a helyzet, megjelölve több olyan konkrét szervezeti mechanizmust, ami ezt lehetővé teszi, mindegyiket konkrét esetekkel illusztrálva (Barnett-Finnemore 2017). Jellegzetes megbízó/megbízott (principal-agent) problémát látnak itt, azaz az ezzel foglalkozó elméletnek abból a tételéből indulnak ki, hogy a megbízott soha nem pontosan azt teszi, amit a meg-

Lásd az „OECD and PISA tests are damaging education worldwide - academics” címü cikket. The Guardian, 2014. 05. 06. 
bízó vár tőle, és az utóbbi eldöntheti, meddig érdemes ebbe belenyugodnia, mikor válik ez a számára ráfizetésessé.

A téma egyik alapvető kézikönyvének számító mű szerzője az olyan nemzetközi szervezeteknek, mint amilyen az OECD, három eltérő szerepét különbözteti meg: az eszköz, az aréna és az ágens szerepeket (Archer 2014). Az első éppen arra utal, aminek kizárólagosságát az imént említett szerzők kétségbe vonták: ebben az esetben az alapító tagállamok egyszerủen saját céljaik elérésére használják a szervezetet. Az eszközt használó ágens persze nem csak a tagokból álló közösség egésze lehet: esetenként lehet ez csupán egyikük, aki a többit nyíltan vagy számukra észrevehetetlen módon ráveszi saját akaratának elfogadására. Az OECD oktatással kapcsolatos történetében több olyan esetet lehet felidézni, amikor a legnagyobb finanszírozó és egyben a szervezet legfontosabb alapítója, az Egyesült Államok akarata érvényesült.

Hogy csak egy esetet említsek azok közül, melyeknek személyesen is részese voltam: ilyen volt, amikor az amerikaiak az oktatáskutatásnak azt a felfogását próbálták globális szinten elfogadtatni, amely a No Child Left Behind törvényben jelent meg, és amely a randomizált kísérleti kipróbálás módszerét helyezte mindenek fölé. ${ }^{2}$ Ebből született az OECD „Tényeken alapuló politikakutatás az oktatásban” címü programja (OECD 2007). Ez az eset azonban rögtön azt is mutatja, milyen korlátokba ütközhet, amikor az egyik tagállam próbálja eszközként használni a szervezetet: a program ugyanis nem úgy alakult, ahogyan azt a kezdeményezői elképzelték, a többi tagállamnak sikerült más irányba terelnie. A tényekre épülő szakpolitikával foglalkozó projektben a randomizált kísérleti kipróbálás helyett a tudomány és a szakpolitika közötti párbeszéd és ennek intézményei, a közvetítő ügynökségek (brokerage agencies) kérdése került a középpontba.

Az imént említett mü (Archer 2014) az aréna szerepet emelte ki második helyen. A szerző ezzel arra is utal, hogy az OECD olyan kommunikációs fórum vagy platform, ahol különböző vélemények, szakmai elképzelések, szakpolitikai megközelítések képviselői találkoznak és vitatkoznak egymással, amiből új gondolatok és új tudás születhet. Olyan tér, melyben ütközni tudnak egymással az eltérő álláspontok, ahol érvek érvekkel szembesülnek, és ahol láthatóvá és érthetővé válhatnak olyan dolgok, melyeket a zárt nemzeti rendszerekben élő, és ezért szükségképpen beszükült perspektívába szorított szereplők nem láthatnak meg, és nem tudnak jól értelmezni.

Alig pár évvel a CERI létrehozása után, a hetvenes évek elején egy amerikai oktatáskutató, aki abban az időben az OECD munkatársaként dolgozott, így írt a szervezet működéséről: „Minden projektet olyan irányitó csoportok aktív támogatásával és részvételével végeznek, melyek tagjai a tagállamokat képviselik. Ennek eredményeképpen olyan széles együttmüködési hálózat keletkezett, amely az oktatási innováció és kutatás területén felelösséggel biró egyénekböl, intézményekböl és hatóságokból áll." (Austin 1972.) Ez azóta sem változott. Igen sok ilyen „irányító csoportnak” (steering group) vagy „tanácsadó testületnek" (advisory group) voltam tagja. Az előbbiek nagyon hasonlóak ahhoz, amilyen az Igazgató Tanács, csak éppen az üléseik egy konkrét témára fókuszálnak, az utóbbiak nem sokban különböznek attól, amivel a speciális téma megvitatására szervezödött nemzetközi tudományos szemináriumokon találkozunk. A résztvevők nagy része egye-

Erről részletesebben lásd Az oktatáskutatás globális trendjei című könyvem „A tényeken alapuló megközelítés" címü fejezetét (Halász 2013; http://halaszg.elte.hu/download/Oktataskutatas_MTA.pdf). 
temeken vagy kutatóintézetekben dolgozó, az adott témára specializálódott oktatáskutató, aki saját szakmai tudását és véleményét hozza be a vitákba.

A CERI esetében - az OECD-ben egyedülálló módon - ez az Igazgató Tanácsban is így van. A szervezet mandátumát meghatározó alapdokumentum explicit módon megfogalmazza, hogy ebbe a testületbe a tagállamoknak olyan kiemelkedő szakértelemmel bíró személyeket kell delegálniuk, „akik a szakpolitika felé erős kapcsolatokkal rendelkező kutatók, vagy az oktatáskutatás és innováció felé erős kapcsolatokkal rendelkező szakpolitikai döntéshozók" (OECD Council 2016). A CERI GB az OECD egyetlen olyan magas szintű (a Tanácsnak közvetlenül alárendelt) állandó testülete, ahol a delegáltak előtt nem országuk névtáblája jelenik meg, hanem saját nevük, és amelynek tagjai explicit módon arra kaptak bátorítást, hogy saját szakvéleményüket, és ne egyszerüen országuk álláspontját fejtsék ki.

$\mathrm{A} z$ alatt a hosszú idő alatt, amíg a CERI GB és más szakmai testületek tagjaként a szervezet munkájában részt vettem, ritkán találkoztam azzal, hogy a résztvevők a diplomáciai protokoll formális szabályait követve viselkedtek volna: ugyanúgy vitatkoztak, ugyanúgy érveltek, ahogyan saját egyetemük vagy tudományos társaságuk ülésein teszik. Nem politikai alkudozások folytak, hanem nyílt szakmai vita, olyankor is, ha a tagok között egészen magas rangú kormánytisztviselők voltak jelen. Azok, akik ezekben a folyamatokban részt vesznek, olyan „episztemikus közösséget” (Haas 1992) alkottak, melynek tagjai a tudományos megismerés racionális keretei között mozogva, közösen próbálnak magyarázatokat keresni az oktatás világában megfigyelhető jelenségekre, és megoldásokat kitalálni az azonosított problémákra.

E közösség tagjait - a CERI GB korábban idézett mandátuma szellemének megfelelően - összeköti egy fontos közös sajátosságuk: egyszerre beszélik a tudományos kutatás és a szakpolitika nyelvét. Ha kutatók, szinte mindig szakpolitikai relevanciával bíró kutatásokat végeznek, és fontosnak tartják a szakpolitikusokkal történő párbeszédet. Ha szakpolitikusok, legtöbbször van kutatói hátterük, használják a tudományos kutatás eredményeit, és abban hisznek, hogy a szakpolitikai döntéshozatalnak a tényeken kell alapulnia.

$\mathrm{A} z$ aréna szó küzdőteret jelent, de ebben az esetben talán pontosabb lenne a kommunikációs fórum vagy platform szó használata. Az OECD-ről írt egyik leggazdagabb elemzés szerzői interjúk sokaságát készítették olyan személyekkel, akik különböző szerepekben részt vettek a szervezet programjaiban, és azt találták, kivétel nélkül mindenki említette a tanulás szót, amikor ki kellett emelniük a részvételük legfontosabb hozadékát (Carroll-Kellow 2011). Az OECD inkább tekinthető a szakpolitikai tanulás, mintsem a szakpolitikai érdekküzdelmek színterének. E tanulás természetesen a (nemzetközi) politika által determinált térben zajlik, melyben az érintett országok nemcsak kooperálnak, hanem versengenek is egymással, és amelyet arra használnak, hogy egymást ellenőrzés alatt tarthassák. Ez az ellenőrzés azonban az alkalmazott módszereknek és a kialakult munkastílusnak a hatására kölcsönös tanulássá és közös tudásépítéssé tudott alakulni.

A korábban említett elemzésben a kormányközi szervezetek harmadik szerepe az ágens szerep. Mint utaltam rá, ez az, ami talán a legvitatottabb, és ez az, ami a leginkább felkelti a kritikus elemzők figyelmét. Azokét, akik szerint az ilyen szervezetek valójában már nem azt teszik, amiért alapítóik létrehozták őket, hanem saját agendát alakítanak ki, és ezt követve, lényegében felhatalmazás nélkül maguk kezdik formálni a nemzeti 
rendszereket. A téma egyik gyakran idézett kutatója, aki maga is Clive Archer említett elemzéséből indult ki, ezt helyezi az első helyre (Centeno 2021). Ahogy más szerzőket is idézve fogalmaz: „a kormányközi szervezetek olyan bürokráciák, melyek a hatalom kulturálisan legitim formáját testesitik meg, és a létrehozóiktól önállósuló hatalmi központokká válnak."

A nemzetközi szervezetek, miután önálló életre kelnek, nem pont úgy viselkednek, mint ahogyan azt alapítóik elképzelték. Barnett és Finnemore idézett tanulmánya (2017) szerint ez nem is lehet másképp. Logikusan következik ez abból a Max Webertől eredeztetett elméletből, mely szerint előbb-utóbb minden bürokrácia elkezd saját célokat követni. A nemzetközi szervezeteket létrehozó államok e tekintetben ellentmondásos módon viselkednek. Egyfelől ellenőrzésük alatt akarják tartani az általuk létrehozott intézményt, másfelől abban érdekeltek, hogy ez hatékony, speciális szakértelemmel rendelkező szervezetté váljék. E speciális szakértelem teszi képessé a nemzetközi szervezetet arra, hogy önállóan cselekedjék, és a szakértelméből fakadó befolyását akár megbízóitól független módon gyakorolja. Ezt fogalmazta meg szemléletes módon a PISA vizsgálat hatásainak egyik elemzője ezekkel a szavakkal: „a technikai farok csóválja a tartalmi kutyát" (Goldstein 2017: 55).

Az OECD különösen erős szakmai tekintélye és meggyőző ereje abból fakad, hogy ebben a szervezetben nem a politikusoké, hanem a szakértőké az uralkodó hang. A tagállamok épp annak köszönhetik, hogy egy különlegesen magas szintü tudással és elemző kapacitással rendelkező szervezet szolgálatait élvezhetik, hogy nem próbálják meg közvetlenül befolyásolni a müködését. Emiatt lehetséges az, hogy az OECD-ben nem a politikai alkuké és nem a diplomáciai protokollé a föszerep, hanem a szakértelemé és a tényeken alapuló racionális érvelésé.

$\mathrm{Az}$ OECD globális oktatáspolitika-alakító ágenssé válása egy sajátos szervezeti dinamika eredményeképpen alakult ki a hatvanas és hetvenes évek fordulóján. E dinamika nem egyszerűen a szervezetet alkotó országok akaratát tükrözte, hanem olyan öngerjesztő folyamatot hozott létre, aminek hatásait nem feltétlenül tudatos szándékok alakították. Egy ennek részleteit feltáró elemzés (Centeno 2019) szerint e folyamat azzal a döntéssel kezdődött, melynek nyomán a hatvanas évek végén a szervezeten belül létrehoztak egy oktatási kérdésekkel foglalkozó központot, a CERI-t. E döntéssel a szervezeten belül keletkezett egy olyan fórum, amely „kilógott” a müködés megszokott rendjéből: olyan szereplők bevonását tette lehetővé, akik nem a gazdaság világát képviselték, behozva ezzel egy olyan ágazat problémavilágát, amely hagyományosan inkább a kultúra területéhez kötődött, és amelynek fejlődését nagymértékben alakítják általános humán értékek.

\section{$\mathrm{A} z$ OECD globális hatásának kritikája}

Az OECD globális oktatási hatásaival foglalkozó, egyre bővülő irodalom döntő hányada az önálló politikaalakító ágens szerepet emeli ki, és implicit vagy - gyakrabban explicit módon bírálja a szervezetet. Némi leegyszerúsítéssel azt mondhatjuk, hogy e bírálatokban két - egymástól nem független - tartalmi elem fogalmazódik meg. $\mathrm{Az}$ egyik az, hogy az OECD befolyásával olyan területekre hatol be, ahol nem lenne keresnivalója, mert ez a szuverén nemzetállamok hatókörébe tartozik. A másik az, hogy e befolyás az oktatásról való gondolkodás nem kívánatos formáját erősíti: azt, amely 
e területre nem az egyetemes emberi értékek, hanem a gazdaság szűk perspektívájából tekint. Az oktatás globális kormányzásának olyan szereplőjét látják az OECD-ben, amely nemcsak olyasmit csinál, amire senkitől nem kapott felhatalmazást, de ráadásul azzal, amit csinál, rossz irányba is viszi a dolgokat.

$\mathrm{A} z$ OECD-t bírálók írásaiban leggyakrabban megjelenő, egyértelműen negatív tartalmú jelző a „neoliberális”. A legtöbb kritikus számára a szervezet „bűne” az, hogy az oktatásról való gondolkodás és az erre irányuló szakpolitikai gyakorlat olyan formáját építi és terjeszti, melyet ezzel az eredendően rossz dologra utaló jelzővel jellemeznek. A fogalom eredetileg a közgazdasági gondolkodásnak arra a paradigmájára utalt, amely az állami költekezést támogató, John Maynard Keynes nevéhez köthető megközelítést váltotta fel a hetvenes években, és amely visszatérés volt a piac szerepét hangsúlyozó klasszikus, Adam Smith nevéhez kötött felfogáshoz. Szellemi forrásként leggyakrabban a Chicagói Iskola közgazdászait említik, mindenekelőtt Milton Friedmant. A jelentése később kitágult, és annak az átfogó gondolkodásmódnak és politikának a megjelölésére kezdték használni, melynek Margaret Thatcher és Ronald Reagan voltak az első prominens képviselői. Érdemes megjegyezni: a neoliberális jelzőt szinte szitokszóként használók jelentős hányada meglehetősen kevéssé ismeri e fogalom jelentéstörténetét, és azokat a mögötte meghúzódó történeti folyamatokat, melyek megszületését eredményezték (ehhez lásd pl. Slobodian 2018).

Az oktatás fejlődését alakító globális nemzetközi szervezetek talán legismertebb radikális kritikusa, a korábban már említett Stephen Ball egy 2016-ban megjelent írásában - Yeats apokaliptikus képeket festő versére utalva ${ }^{3}$ - „lomhán araszoló fenevad”-nak nevezi a neoliberális oktatáspolitikát. Ball, aki a bírálók közt nemcsak az egyik legnagyobb hatású, de az egyik legjobban felkészültnek és leginkább tájékozottnak is tekinthető, egy izraeli kollégáját idézve próbálja definiálni e fogalmat. Eszerint a neoliberalizmus „komplex, gyakran inkoherens, instabil, söt ellentmondásos gyakorlatok együttese, melyek a »piac« valamiféle elképzelése körül szervezödnek, ez válik a társadalmi kapcsolatok univerzális alapjává, behatolva az életünk szinte minden területére" (Ball 2016: 1047).

Ball írásában az „araszoló fenevad” egyebek mellett az OECD képében jelenik meg. Ahogy fogalmazott: „a neoliberális reformokat nagyon erös és nagy meggyözö erövel biró ágensek, köztük a Gazdasági Együttmüködési és Fejlesztési Szervezet és a Világbank, a Kereskedelmi Világszervezet, a Nemzetközi Pénzügyi Társaság, az Európai Unió [...], valamint a piac iránt elkötelezett agytrösztök [...], tanácsadók és szakpolitikai vállalkozók sokasága legitimálják" (Ball 2016: 1047-1048).

A neoliberális gondolkodásmódot és társadalmi gyakorlatot célkeresztjükbe fogó elemzők, Ballhoz hasonlóan, hol finomabb módon, hol keményebb stílusban, szívesen „démonizálják” az OECD-t. E bírálatok néha az összeesküvés-elméletek határát súrolják: szerzőik képzeletében a szervezet már-már úgy jelenik meg, mint olyan hely, ahol a világ megrontásán dolgozók találkoznak, hogy kiagyalják, miképpen tudnának nagyobb kárt okozni. A legtöbbjük persze csak dokumentumokból, jobb esetben nem nyilvános levéltári anyagokból, egy-két szakmai rendezvényen szerzett élményből és pár bennfentessel készített interjúkból ismeri a szervezetet. Emellett még egy törésvonal rajzolódik ki: az, amelynek egyik oldalán azok vannak, akik számára természetes, hogy az okta-

The Second Coming (magyarul: A második eljövetel). 
tásról közgazdasági perspektívában is lehet és kell gondolkodni, a másik oldalon pedig azok, akik kétségbe vonják ennek jogosságát.

$\mathrm{A} z$ OECD azon szervezetek közé tartozik, melyekben az oktatás problémavilágának elemzésében a - lehető legtágabb értelemben vett - közgazdaságtani megközelítés az uralkodó. Ilyen mühelyek természetesen nemcsak a nemzetközi szintéren léteznek: ezek megtalálhatóak minden országban, és mindenhol nagy hatással vannak nemcsak a tudományos kutatásra, hanem a kormányzati szakpolitikák alakulására is. A bírálatok célpontjában, a tapasztalataim szerint, nem egyszerüen a neoliberális megközelítés vagy ideológia áll, hanem tágabban az erről történő közgazdaságtani gondolkodás. $\mathrm{A} z$, amely az oktatásra úgy tekint, mint emberi erőforrások termelőjére, és amely az oktatási kiadásokat a bumán tőkébe történő befektetésként értelmezi. A törésvonal másik oldalán azok állnak, akik számára az oktatás célja az emberi kultúra megőrzése, a társadalmi igazságosság biztosítása vagy az egyetemes humán értékek szolgálata. Én magam mindig mesterkéltnek éreztem ezt a szembeállítást, és a kettő között nem éreztem elvi ellentmondást, de az oktatási szakpolitika formálódásának létező intézményrendszereiben - legyen szó akár nemzetközi, akár nemzeti intézményekről - ezek kétségtelenül mindenütt és mindenhol szembekerülnek egymással.

Az oktatás „ökonomizálásának” (economization of education) bírálói számára a nemzetközi szervezetek - nemcsak az OECD, hanem akár a globális trendekhez alkalmazkodó, korábban a „filozófusok által uralt” (Elfert 2018) UNESCO is - érthető módon váltak kedvelt célponttá. A témát átfogó módon elemző müvében Joel Spring a Chicagói Egyetem olyan közgazdászaihoz köti ezt a gondolkodásmódot, mint Milton Friedman, Theodore Schultz, Gary Becker és James Heckman, akik mind Nobel-díjat kaptak munkásságukért (Spring 2015). Ök az oktatásról való neoliberális közgazdasági gondolkodás atyjai. $\mathrm{Az}$ OECD közismerten úttörő volt a humán tőke elméletének konkrét szakpolitikai gyakorlattá alakításában. Az oktatásban játszott szerepének történeti elemzői alaposan feltárták, hogyan született meg - döntően amerikai befolyás hatására - az a szakpolitikai gondolkodásmód, amely az oktatást nem fogyasztásnak, hanem befektetésnek tekinti, és amely arra serkenti az államokat, hogy növeljék az erre szánt kiadásaikat (lásd pl. Elfert 2019). Sajátos ellentmondás, hogy az iskolák világát fenyegető veszélyek miatt aggódó kritikusok ezt aggodalommal fogadják.

Ennek az aggodalomnak egyik forrása az lehet, hogy a közgazdászok - így azok is, akik az OECD elemzéseit készítik - nemcsak azt szorgalmazták, hogy a társadalmak több pénzt fordítsanak az oktatásra, hanem azt is, hogy ezt lehetőleg ne herdálják el. Azaz elsősorban olyan emberi képességek fejlesztésére fordítsák, melyekre az életben történő boldoguláshoz és az eredményes munkavégzéshez van szükségünk. Ez az igény nem a közgazdászok elméjében keletkezett: az iskoláktól elsősorban ezt várják azok a társadalmak, melyek elfogadták, hogy erőforrásaik egyre nagyobb hányadát az iskolai oktatásra és az emberi tanulás támogatására fordítsák. Másik forrása az lehet az aggodalmaknak, hogy a közgazdászok - nemcsak az OECD-ben, hanem hasonlóképpen más nemzeti és nemzetközi szervezetekben - nem elégednek meg azzal, hogy a politikusok általános szintjén deklarálják, hogy a növekvő kiadásokat az oktatási rendszerek hatékonyan fogják felhasználni. Azt is szükségesnek látják, hogy legyenek olyan mérhető mutatók, melyek segítségével tényekre alapozva meg lehet állapítani, hogy ez valóban megtörténik-e. Az OECD sokak körében a legnagyobb csodálatot kiváltó, ugyanakkor a kritikai irodalom által a legerősebben bírált jellemzője, hogy az oktatás területén ilyen 
mutatók sokaságát alkotta meg. Erről szól a szervezet legnagyobb hatású oktatással kapcsolatos programja, az INES (erre rögtön visszatérek).

A hatékonyságot, a menedzsment minőségét, a teljesítmény mérhetőségét és az elszámoltathatóságot hangsúlyozó „neoliberális agenda” kétségtelenül meghatározó módon jelen van az OECD oktatással kapcsolatos tevékenységében. Fontos azonban ehhez hozzátenni még valamit, amit az elemzők egyike egy interjúalanyát idézve így fogalmazott meg: „egyes tagállamok azt vetették az OECD szemére, hogy túlságosan szociáldemokrata módon viselkedik" (Kallo 2020: 8).

Megint csak saját személyes élményeimmel tudom a fentieket alátámasztani. Az Oktatáspolitikai Bizottság, a CERI Igazgatótanácsa és más oktatással foglalkozó testületek ülésein gyakran volt olyan érzésem, hogy ami ott történik, inkább hasonlít egy, a politikai paletta bal oldalán található társadalmi szervezet belső világának történéseire, mint arra, amit egy liberális vagy konzervatív orientációjú szervezetben várnánk. Nem nagyon emlékszem olyan hozzászólásokra, melyek a piac pozitív szerepét hangsúlyozták volna, annál inkább olyanokra, melyek fókuszában az esélyegyenlőség, a társadalmi szolidaritás és az igazságosság, valamint egyre inkább a fenntarthatóság hangsúlyozása állt.

\section{"Számokkal történő kormányzás”}

Az OECD-nek az oktatás globális fejlődésére gyakorolt hatásával foglalkozó elemzések többsége az indikátorok, azaz a mérhető mutatók, ezen belül különösen a PISA vizsgálat által termelt adatok hatására fókuszál. Az indikátorok nagy erejü kormányzási eszközök. Ahogy egy, a témával foglalkozó kézikönyvben olvashatjuk: „A mérbető mutatók fejlesztése révén a mögöttes rendezetlen társadalmi világ konkrétságot és kezelhetöséget nyer: könnyebben megismerhetövé, elméletekkel jobban uralhatóvá, így könynyebben kormányozhatóvá, a cselekvés és beavatkozás számára inkább megközelithetővé lesz" (Bhuta-Malito-Umbach 2018). Az OECD egyik meghatározó jellemzője ennek az eszköznek az alkalmazása a globális kormányzás világában. Az oktatási ágazatban a témával foglakozó irodalom ezt gyakran azokhoz a tanulmányokhoz kapcsolja, melyek egy, e fejezet címével azonos nevủ skóciai kutatási programból születtek. ${ }^{4}$

Fontos hangsúlyozni: az indikátorok kormányzási eszközként történő használata természetesen nemcsak a nemzetközi szervezetek és a globális kormányzás szintjén jellemző, és az utóbbi szinten sem csak az OECD sajátossága. Olyan általános eszközről van szó, melynek nagy múltja van nemzeti rendszereken belül és a globális kormányzás más ágensei is használják, sőt, az OECD-t megelőzően kezdték alkalmazni. A Világbank már a hetvenes években létrehozott indikátorrendszert a fejlesztési hitelekről való döntései megalapozásához, ami hosszabb ideig csak a saját munkatársai számára volt hozzáférhető, de később nyilvánosan elérhetővé tették (Anheier 2018). E szervezetben a komplex társadalmi jelenségek, ezen belül oktatási folyamatok értékelésére alkalmas indikátorok fejlesztése és alkalmazása ma is kiemelt figyelmet kap. Ilyennek tekinthető a korában említett SABER rendszer, melynek elméleti hátterét összetettebbnek és mélyebbnek látom, mint azt, ami az OECD oktatási indikátor programját jellemzi.

\footnotetext{
A kutatási projekt bemutatását lásd itt: https://www.ces.ed.ac.uk/old_site/research/FabQ/uk.html. Továbbá: Grek-Ozga 2008.
} 
Nem meglepő, hogy a rendszerek és szakpolitikák értékelésére használt indikátorok fejlesztése az OECD-ben a kilencvenes években elérte az akkor már egyre nagyobb figyelemmel követett oktatási ágazatot is, és létrejött a szervezet oktatási indikátor programja, az INES. Ez egy hosszú, a hetvenes évek elejére visszanyúló fejlődési folyamat eredménye. Az Oktatási Bizottság már 1973-ban tárgyalt és jóváhagyott egy erre vonatkozó javaslatot, melynek „A Framework for Educational Indicators to Guide Government Decisions" volt a címe. ${ }^{5}$ Ez jól tükrözte a szervezeti oktatással kapcsolatos korai megközelítését: az inputokban és outputokban gondolkodó, a rendszerhatékonyság növelésének lehetőségeit kereső szemléletet.

Ahogyan az jól érzékelhető Kádárné Fülöp Juditnak ebben az Educatio-számban megjelent, az INES történetét is bemutató írásából, a „számokkal történő kormányzás” - és azoknak az intézményi mechanizmusoknak a kiépítése, melyek a nemzetközi térben teszik ezt lehetővé - döntően ahhoz a társadalomkutatói közösséghez kapcsolódik, amely a tudásra épülő racionális kormányzás ideáját követte, és amelynek számára az OECD jelentette nemzetközi tér általában kedvezőbb terepet kínált, mint a nemzeti politikai környezet. Itt jóval kevésbé kellett számolni történetileg kondicionált kulturális és ideológiai szembenállásokkal vagy az erőforrásokért történő küzdelem által meghatározott pártpolitikai küzdelmekkel, mint nemzeti szinten. Itt jóval nagyobb volt a receptivitás a szakpolitika tényekre alapozása iránt, és sokkal nagyobb esélye volt annak, hogy a tudás váljon a kormányzás egyik legfontosabb eszközévé.

A „számokkal történő kormányzás”, azaz az indikátorok szakpolitikai felhasználása azzal a céllal, hogy kívánatos irányba tereljék a társadalmi alrendszerek, ezen belül az oktatási rendszerek fejlődését, sokak által kutatott problémavilágot alkot. A témával foglalkozó tanulmányok egyike (Bartl-Papilloud-Terracher-Lipinski 2019) három olyan okot emel ki, melyekre az indikátorok iránti politikai és társadalmi érdeklődés a hetvenes éveket követő időszakban visszavezethető volt. Az első ezek közül a kormányzott rendszerek komplexitásának növekedése, ami kikényszerítette, hogy bonyolult folyamatokat egyszerü, az adott folyamat lényegi elemeit kiemelö mutatókkal lehessen megragadni. Ez minden területen felerősítette az igényt, hogy korlátozott számú, mérhető változóval próbáljunk bonyolult társadalmi jelenségeket leírni és az ezeket magyarázó oksági összefüggéseket is feltárni. A másik ok a teljesítményérdekeltség és a hatékonysági szempontok előtérbe kerüléséhez az elszámoltathatóság politikai felértékelődéséhez, azaz tágan az Új Közmenedzsmenthez (NPM) köthető. Ennek hatására kezdték el a közszférában is egyre inkább alkalmazni a vállalati vezetők által mindig is használt mérhető mutatókat, melyekkel nyomon lehet követni a bevételek és a termelékenység alakulását. Ezek nemcsak időben figyelmeztetik a vezetést, ha valahol be kell avatkozni, de arra is szolgálnak, hogy meggyőzzék a tulajdonosakat vagy a befektetőket arról, hogy a dolgok jó irányba mennek. A harmadik ok technikai jellegü. Az adatgyüjtési és adatfeldolgozási technológiák, a statisztikai módszertan és az e területeken rendelkezésre álló szakértelem fejlődése olyan mérési lehetőségeket és a mérési adatok kommunikálásának olyan új formáit teremtette meg, melyek e területen a korábbiaknál komolyabb fejlődést tettek lehetővé.

Lásd az OECD Observer „Measuring performance in the field of education” címü cikkét. N 65/August 1973. (https://www.oecd-ilibrary.org/docserver/observer-v1973-4-en.pdf?expires=1628158990\&id=id\&accna me $=$ guest $\&$ checksum $=2$ C8A3B04ABDA8649AEFBDDE15E778EB3) 
Ezeket az okokat természetesen lehetne másokkal kiegészíteni, de a lényeg az, hogy a külső és belső feltételek az oktatási ágazatban is adottak voltak arra, hogy megerősödjék a „számokkal történő kormányzás”, és az OECD különösen kedvező terepet nyújtott arra, hogy ez a nemzetközi térben is egyre nagyobb szerepet kapjon. Az OECD-nek az oktatás globális fejlődésére gyakorolt hatása a kétezres évektől kezdve elsősorban ezen a csatornán keresztül érvényesülhetett. Azon a mechanizmuson keresztül, melyet néha a „name and shame” kifejezéssel („mutass rá, hadd szégyellje magát!”) írunk le, és amit látványosan felerősíthet a nagy meggyőző erővel bíró adatok birtoklása. Az OECD az oktatás területén mindenekelőtt ennek a mechanizmusnak köszönheti azt a képességét, hogy közvetlen jogi és pénzügyi hatalmi eszközök nélkül módosítani képes azt a fejlődési vonalat, amelyet a nemzeti oktatási rendszerek követnek.

\section{Az OECD és a kormányok közötti párbeszéd}

A nemzeti szintű politika természetesen képes felülírni az OECD-nek azokat az üzeneteit, melyeket megfogalmazóik a tudásra és a tényekre próbálnak építeni. Ennek illusztrálására érdemes felidézni Lengyelország esetét, ahol az elmúlt évtizedben a hatalomra került populista, nemzeti-konzervatív erők felülírták az OECD felől érkező tudásalapú üzenetet, és elkezdték restaurálni a korábbi reformok előtti struktúrákat, annak ellenére, hogy az OECD vizsgálatai szerint e reformok látványosan javították a lengyel oktatási rendszer eredményességét. Talán jól segítheti e folyamat megértését, ha felidézem, amit a lengyelországi oktatási viszonyokkal foglalkozó kutató kollégám elbeszéléséből hallottam. Amikor interjúkat készített lengyel oktatáspolitikusokkal, feltette nekik a kérdést: „De hát nem ismeritek az OECD adatait? Nem tudjátok, hogy éppen azoknak a reformoknak nyomán lettek eredményesebbek a lengyel iskolák, amiket most leromboltok?” A tipikus válasz, amit erre kapott, valami ilyesmi volt: „Igen, ismerjük az adatokat. De nekünk, politikusoknak az a dolgunk, hogy a nép akaratát végrehajtsuk, a választási győzelmünk pedig azt mutatja, az emberek vissza akarnak térni a korábban megszokott struktúrákhoz." Ez az anekdotikus példa talán jól illusztrálja, hogy az a szövetség, amely az OECD-ben „a „tudomány és a szakpolitika találkozására" épül, csak akkor képes hatással lenni a továbbra is nemzeti keretek között müködő oktatási rendszerekre, ha ez a meglehetősen törékeny szövetség nemzeti szinten nem bomlik fel.

Fontos hangsúlyozni, hogy az OECD nemcsak számokkal gyakorolja a globális kormányzást. Amikor a 2008-as pénzügyi és gazdasági válság kitört, sokan - magán a szervezeten belül is - megkérdőjelezték a matematikai modellekkel dolgozó és statisztikai érvelést használó közgazdászok dominanciájának legitimitását. Explicit módon megfogalmazódtak ilyen kérdések: „Hogyan lehetséges, hogy ti, akik az egész világon a legjobb minőségű adatok birtokában vagytok, nem tudtátok előre megmondani, hogy valami nagyon nagy baj készül?” Egyes tagállamok képviselői egyenesen a felelősök megnevezését és felelősségre vonásukat követelték.

Ennek nyomán indította el a szervezet a "Gazdasági Kibívások Új Megközelitései” $(\mathrm{NAEC})^{6}$ elnevezésű programját. Ennek köszönhető, hogy felértékelődött az általá-

\footnotetext{
NAEC $=$ New Approaches to Economic Challenges (a program honlapját lásd itt: https://www.oecd.org/ naec).
} 
ban kvalitatív eszközökkel dolgozó komplexitástudomány és történettudomány szerepe a gazdasági és társadalmi folyamatok értelmezésében és értékelésében olyan mértékben, ahogyan ez a válság előtt elképzelhetetlen lett volna. Ugyanebbe a vonalba illeszkedik a korábban indult „Making reforms happen” elnevezésű program, melyet eredetileg a „reformok politikai gazdaságtana” névvel jelöltünk. Ennek az oktatási ágazatban történő alkalmazása ${ }^{7}$ épít ugyan az indikátorrendszerre, de alapvetően kvalitatív elemzésekre támaszkodik, és a hangsúly a tagországok kormányainak nyújtott közvetlen, célzott tanácsadáson van.

A kormányoknak történő közvetlen tanácsadásnak a kezdetektől minden ágazatban, így az oktatásban is meghatározó része az OECD tevékenységének. Én magam tíz alkalommal, tíz különböző országban voltam tanácsadó olyan OECD-misszióban, ahol nemzeti minisztériumoknak kellett egy-egy területen vagy átfogó módon szakpolitikai támogatást adnunk, közvetlen kapcsolatba lépve a nemzeti szakpolitikai tér legkülönbözőbb szereplőivel. Az ilyen missziók olyan kommunikációs teret hoznak létre, melyben a hangsúly a dialóguson van, és bár ebben fontos szerepet játszanak a számokra vagy adatokra történő hivatkozások, nem ez a lényeg. Az ilyen missziók a közös tudásteremtés, a kölcsönös tanulás és tudásmegosztás mellett a nemzetközi bizalomépítés és - ami ennek fontos eszköze - a társak általi ellenőrzés eszközei. Az OECD számára ezek az országokra gyakorolt hatás fontos csatornáját jelentik, de valójában ilyenkor nem egyszerúen az OECD hat a tagországokra, hanem a tagországok is egymásra, az OECD-t használva a kölcsönös hatásgyakorlás intézményes eszközeként.

Végül a hatásgyakorlás sokféle módja közül még egyet érdemes itt kiemelni: ez olyan átfogó horizontális stratégiáknak a megalkotása, melyeket a tagállamok közvetlenül felhasználhatnak, és gyakran fel is használnak akkor, amikor nemzeti stratégiákat alkotnak. Kettő olyat említenék, melyek alakításába a CERI Igazgató Tanácsa delegáltjaként bekapcsolódhattam: az egyik az Innovációs Stratégia, ${ }^{8}$ a másik a Képességstratégia. ${ }^{9}$ Ezek közül különösen az utóbbi esetében figyelhetünk meg látványos hatást, mivel itt az OECD egy sor országban közvetlenül támogatta nemzeti képességstratégiák létrehozását, ami az OECD-tudás közvetlen nemzeti szintű alkalmazásának tekinthető. ${ }^{10}$

\section{A hatásgyakorlás intézményi mechanizmusai}

Többször tettem utalást azokra a mechanizmusokra, melyeken keresztül az OECD az oktatási rendszerek globális fejlődését - ezen belül természetesen a magyarországi oktatási rendszer alakulását is - befolyásolta és befolyásolja. E tanulmány záró részében - a rendelkezésre álló szúk terjedelmi keretek között - ezekről lesz szó.

$\mathrm{A} z$ első dolog, amit fontosnak tünik kiemelni, az az, hogy az OECD-re nem érdemes pusztán úgy tekinteni, mint külső ágensra, amely kívülről befolyást gyakorol a nemzeti rendszerekre. A korábban említett három szerep közül a fórum szerep azt is jelenti, hogy ez az ágens nemcsak hatást gyakorol, hanem maga is hatásoknak van kitéve. A tagálla-

Lásd a "Implementing Policies: Supporting Effective Change in Education” programot (https://www.oecd.org/ education/implementing-policies).

8 A kapcsolódó honlapot lásd itt: https://www.oecd.org/site/innovationstrategy

9 A kapcsolódó honlapot lásd itt: https://www.oecd.org/skills

10 A Képességstratégia Tanácsadó Csoport (Skills Strategy Advisory Group) üléséről évekre visszamenően rendelkezésre állnak elemző beszámolók. 
mok közössége sokkal inkább alakítja, amit ő tesz, mint amennyire ő alakítja azt, amit a tagállamok tesznek. A szervezetről írt, korábban már idézett könyvüknek Carroll és Kellow (2011) nem véletlenül adták ezt az alcímet: „A szervezeti adaptálódás elemzése”. Ha példát kellene mondanom olyan szervezetre, melyben a tanulószervezetek minden jegye megtalálható, elsőként talán az OECD-t említeném.

Mindig úgy láttam, hogy az OECD olyan kulturális modellt közvetít az országok felé, melyben a tanulást az ehhez nélkülözhetetlen nyitottság és bizalom támogatja, és ahol a tudás és a tényekre hivatkozó racionális érvelés uralkodik. Ebben a kultúrában nem kaphatnak hangot az emberi tudatlanságot kihasználó, identitásalapú vagy „törzsi hovatartozásra” apelláló populista megközelítések. E szervezet a természeténél fogva kevéssé racionális politika racionalizálásának kultúráját hordozza, erősítve a hitet, hogy ez nem teljesen reménytelen vállalkozás. Az OECD által gyakorolt hatásnak ez lényegi eleme: döntően ebből fakad a szervezet hitelessége. Ehhez - visszautalva a korábban említett, az oktatási ágazatban különösen nagyszámú kritikus elemzésre - érdemes hozzátenni: soha nem találkoztam olyan kritikával, melynek a szerzője az OECD tevékenységét saját kormánya tevékenységével hasonlította volna össze. A legtöbb kritikus elemzés azért ad megtévesztő képet az OECD-ről, mert azt az érzetet kelti az olvasókban, hogy a kritikát megfogalmazók saját nemzeti kormányukról jobb véleménnyel lennének. Mintha implicit módon azt sugallnák, vissza kell szorítani az OECD befolyását, és a nála jobb minőségű szakpolitikát követő nemzeti kormányoknak kell visszaadni a dolgok alakításának kizárólagos lehetőségét. Úgy vélem azonban, a kritikusok jelentős része saját kormányával még kevésbé lehet elégedett, mint az OECD-vel, de kritikájukat különböző megfontolásokból mégis szívesebben fordítják a nemzetközi ágens ellen.

$\mathrm{A} z$ OECD akár az állandó konferenciák (standing conferences) vagy - hitéleti példával - a zsinatok metaforáival is leírható. Hatása a gondolkodás átalakulásában, a fogalmak jelentésének változásában, új elnevezések kigondolásában ragadható meg. Részben abban, amit Barnett és Finnemore korábban idézett tanulmányukban (2017) patologikus jelenségként, a bürokratikus hatalom forrásait felidézve említenek: az osztályozás, a jelentésadás és a normaalkotás vagy normaterjesztés képességén. Ez azonban pozitív módon is megragadható, hiszen ezek az új, a világban való létezéshez szükséges tudás születésének mozzanataiként is leírhatóak.

Nemcsak az OECD, hanem minden nemzetközi szervezet nemzeti ágenseken keresztül gyakorol hatást. Úgy is fogalmazhatunk, hogy a nemzeti szintű szereplők a saját céljaikat és érdekeiket követve "használják” a nemzetközi szervezeteket, amelyek azért tudnak hatást gyakorolni, mert a nemzeti szakpolitikai térben vannak olyan szereplők, akiknek szükségük van erre a hatásra, és képesek azt a saját szolgálatukba állítani.

E nemzeti rendszereken belül látható mechanizmusokról az Európai Unióval kapcsolatban korábban részletesen írtam (Halász 2002b): itt hasonló folyamatokról van szó. Ennek remek elemzése olvasható egy finn kutató értekezésében, aki a PISA vizsgálat finnországi hatásait vizsgálva a „domesztikáció” fogalmát használja. Érdemes hosszabban idézni, ahogyan e mechanizmusokat bemutatja:

„A helyi szereplők nem egyszerűen exogén politikai modellekre reagálnak saját országuk érdekeiből kiindulva. Ha tehetik, nemzetközi összehasonlító adatokhoz folyamodnak, hogy saját céljaikat a belpolitikában előmozdítsák. Megfontolt retorikával irányítják rá honfitársaik figyelmét a más országokban alkalmazott szakpolitikákra vagy a saját országukban már meglévő gyakorlatokra, így különféle modelleket építenek fel 
vagy bizonyítékokat mutatnak be ezek sikeréről. E helyi beszámolók révén a globális politikai elképzelések összefonódnak a helyi szereplők érdekeivel és indítékaival. Ezáltal az eredetileg globális kontextusban felvetett ötlet exogén eredete eltűnik, és belföldinek kezdik tekinteni. Az új politika akár a nemzet jellemző vonásának is tekinthető, és más országokba is átvihető, ezáltal reprodukálva a globális társadalmi változások körforgását." (Rautalin 2013.)

Az, amit a finn kutató a domesztikáció szóval jelöl, arra is utal, hogy a külső hatások a nem eléggé figyelmes elemző számára akár láthatatlanná is válhatnak, ezek feltárása csak olyan, komoly adatgyüjtésre épülő elemzés képes, mint amit ő maga is készített. A láthatatlanná válás egyik formája az Európai Unió tagországaiban, így Magyarországon is az, amikor az OECD-hatások az Unió közvetítésével érnek el minket.

Az OECD és az Európai Unió kapcsolatáról, ezen belül arról, hogy az Unió milyen módon használja az OECD-indikátorokat saját kormányzási gyakorlatában és ezzel kapcsolatban milyen dilemmák merülnek fel, hosszabban írtam egy korábban már említett, az Európai Parlament felkérésére készült elemzésben (Halász 2016). Itt annyit érdemes ebből felidézni, hogy az Európai Unióban mindig voltak olyan szakpolitikusok és kutatók, akik kifejezetten károsnak tartják, hogy az Unió „túlságosan” támaszkodik az OECD-re, és azt szorgalmazzák, építsen ki saját értékelő rendszereket - pl. a PISA-hoz hasonló európai tanulmányi eredményesség mérési rendszert. Úgy vélik, az angolszász és a kelet-ázsiai országok túlságosan erős hatást gyakorolnak az OECD megközelítésére, és ezt az Európai Uniónak semlegesítenie kellene. Korábban közismerten voltak súrlódások az OECD és az Európai Bizottság között, de az elmúlt egy-másfél évtizedben egyszer sem tapasztaltam olyat, hogy ezek szignifikánsan eltérő módon közelítettek volna oktatási szakpolitikai kérdésekhez.

$\mathrm{A} z$ OECD programjaiba való bekapcsolódás - egy-két kivételt leszámítva - csak a nemzeti kormányokon keresztül lehetséges. Az, hogy Magyarországon az OECD milyen hatással lehet az oktatás fejlődésére, alapvetően attól függ, a kormány akarja-e ezt a hatást. Az OECD-tudás természetesen nemcsak kormányzati csatornákon juthat be az országba: a szervezet nyilvános kiadványai és adatbázisai bárki számára elérhetőek. Az oktatáspolitika formálásába bekapcsolódó nem kormányzati szereplők fel tudják használni ezt a tudást, és ezt gyakran meg is teszik. A kormányzati csatorna azonban meghatározó fontosságú: a hatás azokban az országokban jelentős, ahol kormányzati szereplők tudatosan építenek az OECD-vel történő együttmüködésből fakadó lehetőségekre. Ez bizonyos országokban rendkívül erős.

Ha nincs kormányzati érdeklődés, az OECD hatása igen alacsony szintre csúszhat vissza. Személyes tapasztalatom, hogy az elmúlt egy évtizedben az oktatási ágazatban Magyarország egyre inkább passzívvá vált. Ezt némileg oldotta az oktatásért való ágazati felelősség kettéválása: a felsőoktatási és szakképzést felügyelő Innovációs és Technológiai Minisztérium inkább igényli az OECD-tudás felhasználását, mint az alap és középfokú oktatást felügyelő Emberi Erőforrások Minisztériuma. Az utóbbiban ezzel kapcsolatban az elmúlt évtizedben meglehetősen nagy érdektelenséget érzékeltem (ez alól főképp a PISA vizsgálat jelentett kivételt, amit teljes mértékben az utóbbi szaktárca, pontosabban annak háttérszervezete, az Oktatási Hivatal ellenőriz). Az OECDhatások beszűkülésének részben a magyarországi közoktatási szakpolitikai-tartalmi orientációja, ezen belül a modernizációban való érdekeltség visszaszorulása volt az egyik oka. Ezt jó illusztrálta a Nemzeti alaptanterv 2018-19-ben zajlott felülvizsgálata. Ezt 
ennek szakmai iránytója közvetlenül hozzákapcsolta az OECD e területen folyó programjához, ${ }^{11}$ a szakértők által kidolgozott javaslat kormányzati fogadtatása azonban azt jelezte, e modernizációs törekvés az ágazat irányítóiban nem keltett érdeklődést.

$* * *$

Összefoglalásként azt fogalmaznám meg, hogy e tanulmány elkészítésének idején és az azt megelőző években Magyarország azon kevés ország közé került, amely az oktatási ágazatban töredékét sem használja ki annak a különleges potenciálnak, melyet az OECD-tagság jelent. Úgy is fogalmazhatnánk, a modernizáció iránt kevéssé nyitott, az OECD-tagországok többsége által túlhaladottnak tekintett szakpolitikai paradigmát követő ágazati kormányzati filozófia és cselekvés kevéssé kedvez annak, hogy az OECD hasonló hatással lehessen az oktatás fejlődésére, mint más tagországokban. Egy olyan klub tagjai vagyunk, melynek értékei távol kerültek azoktól az értékektől, melyek a magyarországi oktatási ágazati szakpolitikát - különösen a közoktatás területén - aktuálisan orientálják. E tekintetben érdekes lenne megvizsgálni, vajon az OECD oktatási tevékenységét és túlzott befolyását bíráló, egyre bővülő irodalom termelői ajánlanák-e saját kormányuknak a magyar kormány által követett irányvonalat. Számomra ez rendkívül kevéssé valószínűnek tűnik. Sőt, korábbi tapasztalataim alapján megkockáztatnám: ha a kritikus tanulmányok szerzőit az OECD-szakértőként felkérnék, adjanak tanácsot a magyarországi szakpolitikusoknak, a legtöbben olyan dolgokat tanácsolnának, amelyek meglehetősen nagy összhangban lennének az általuk bírált szervezet létező stratégiájával.

\section{IRODALOM}

Anheier, H. K. (2018) Governance Indicators: Development and Assessment. In: H. K. Anheier, M. Haber, M. A. Kayser (eds) Governance Indicators: Approaches, Progress, Promise. Oxford, Oxford University Press. pp. 1-10.

Archer, C. (2014) International Organizations. Routledge.

Austin, G. R. (1972) OECD/CERI: Fostering Cooperation in International Educational Research. Educational Researcher, Vol. 1. No. 11. pp. 5-7.

Avelar, M. (2016) Interview with Stephen J. Ball: Analysing His Contribution to Education Policy Research. Education Policy Analysis Archives, 24. (https://www.redalyc.org/ jatsRepo/2750/275043450049/html/index.html)

Ball, S. J. (2016) Neoliberal Education? Confronting the Slouching Beast. Policy Futures in Education, Vol. 14. No. 8. pp. 1046-1059.

Barnett, M. N. \& Finnemore, M. (2017) The Politics, Power, and Pathologies of International Organizations. In: J. J. KirTon (ed.) International Organization. Routledge. pp. 471-503.

Barti, W., Papilloud, C. \& Terracher-Lipinski, A. (2019) Governing by Numbers - Key Indicators and the Politics of Expectations: An Introduction. Historical Social Research, Vol. 44. No. 2. pp. 7-43.

11 Ez az „Education 2030” program (a honlapját lásd itt: https://www.oecd.org/education/2030-project). Lásd még a Nat reformprojekt honlapján az „Iránytü a jóllétbez - az OECD ajánlásai és az új Nat-tervezet” címủ lapot. 
Bhuta, N., Malito, D. V. \& Uмвасн, G. (2018) Introduction: Of Numbers and Narratives - Indicators in Global Governance and the Rise of a Reflexive Indicator Culture. In: D. V. Malito, G. Uмвасн \& N. Bhuta (eds) The Palgrave Handbook of Indicators in Global Governance. Springer International Publishing. Palgrave Macmillan. pp. 1-29.

Carroll, P. \& Kellow, A. (2011) The OECD: A study of Organisational Adaptation. Edward Elgar Publishing.

Centeno, V. G. (2019) The Birth of the OECD's Education Policy Area. In: C. Ydesen (ed.) The OECD's Historical Rise in Education. Basingstoke. Palgrave Macmillan. pp. 63-82.

Centeno, V. G. (2021) The OECD: Actor, Arena, Instrument. Globalisation, Societies and Education, Vol. 19. No. 2. pp. 108-121.

Elfert, M. (2018) UNESCO's Utopia of Lifelong Learning: An Intellectual History. Routledge.

Elfert, M+ (2019) The OECD, American Power and the Rise of the "Economics of Education" in the 1960s. In: C. Ydesen (ed.) The OECD's Historical Rise in Education. Basingstoke, Palgrave Macmillan. pp. 39-62.

Goldstein, H. (2017) Measurement and Evaluation Issues with PISA. The PISA Effect on Global Educational Governance. In: L. Volante (ed.) The PISA Effect on Global Educational Governance. Routledge. pp. 49-58.

Grex, S. \& Ozga, J. (2008) Governing by Numbers? Shaping Education through Data. Centre for Educational Sociology. University of Edinburgh.

HaAs, P. M. (1992) Introduction: Epistemic Communities and International Policy Coordination. International Organization, Vol. 46. No. 1. pp. 1-35.

Halász G. (2002a) Az oktatás az Európai Unióban - tanulás és együttmüködés. Budapest, Új Mandátum.

Halász G. (2002b) Az OECD tevékenysége az oktatás területén. In: Bábosı́ I., Kárpáтi A. (eds) Összehasonlító pedagógia - A nevelés és oktatás nemzetközi perspektívái. Books in Print. Budapest, 2002. pp. 71-86.

Halász G. (2013) Az oktatáskutatás globális trendjei. Budapest, ELTE Eötvös Kiadó.

Halász G. (2014) Az OECD és az oktatás. In: Széll K. (ed.) Az OECD az oktatásról. Budapest, Oktatáskutató és Fejlesztő Intézet. pp. 7-16.

Halász G. (2016) Evaluation of Education at the European Level. European Parliament, Luxembourg. 2016 (https://www.europarl.europa.eu/thinktank/en/document. html?reference=IPOL_STU(2016)573424)

Kallo, J. (2020) The Epistemic Culture of the OECD and Its Agenda for Higher Education. Journal of Education Policy, Vol. 36. No. 2. pp. 1-22.

OECD (2007) Evidence in Education. Linking Research and Policy. Paris.

OECD Council (2016) Resolution of the Council [C(2016)91/REV1, Annex and $\mathrm{C} / \mathrm{M}(2016) 15$ item 241].

Rautalin, M. (2013) Domestication of International Comparisons: The Role of the OECD Programme for International Student Assessment (PISA) in Finnish Education Policy. Academic Dissertation. University of Tampere.

Slobodian, Q. (2018) Globalists: The End of Empire and the Birth of Neoliberalism. Cambridge (MA), Harvard University Press.

Spring, J. (2015) Economization of Education: Human Capital, Global Corporations, Skillsbased Schooling. Routledge. 
The Guardian (2014) OECD and Pisa Tests Are Damaging Education Worldwide - Academics. 6 May 2014. (https://www.theguardian.com/education/2014/may/06/oecd-pisatests-damaging-education-academics)

Verger, A., Altinyelken, H. K. \& Noveldi, M. (2018, eds) Global Education Policy and International Development: New Agendas, Issues and Policies. Bloomsbury Publishing.

A cikk a Creative Commons Attribution 4.0 International License (https://creativecommons.org/licenses/ by/4.0/) feltételei szerint publikált Open Access közlemény, melynek szellemében a cikk bármilyen médiumban szabadon felhasználható, megosztható és újraközölhető, feltéve, hogy az eredeti szerző és a közlés helye, illetve a CC License linkje és az esetlegesen végrehajtott módosítások feltüntetésre kerülnek. (SID_1) 